\title{
NFIWADS: the water budget, soil moisture, and drought stress indicator database for the German National Forest Inventory (NFI)
}

\author{
Paul Schmidt-Walter ${ }^{1}$ (D) $\cdot$ Bernd Ahrends $^{1} \cdot$ Tobias Mette $^{2} \cdot$ Heike Puhlmann $^{3} \cdot$ Henning Meesenburg ${ }^{1}$
}

Received: 6 November 2017 / Accepted: 10 March 2019 / Published online: 12 April 2019

(C) INRA and Springer-Verlag France SAS, part of Springer Nature 2019

\begin{abstract}
- Key message The NFIWADS database contains aggregated results for the German National Forest Inventory (NFI) plots based on process-based water balance simulations. More than 150 water budget, soil moisture, and drought stress indicators were derived for mature, closed-canopy beech and spruce stands, and provide a basis for the assessment of forest productivity and risks. Dataset is available in the Open Agrar repository (Schmidt-Walter et al 2018) at https:// www.openagrar.de/receive/openagrar_mods_00044576. Associated metadata is available at https://metadata-afs.nancy. inra.fr/geonetwork/srv/fre/catalog.search\#/metadata/2f09d81c-b663-48a0-8b84-0b247bba6d35.
\end{abstract}

Keywords Forest inventory $\cdot$ Soil water availability $\cdot$ Water balance $\cdot$ Drought stress $\cdot$ Climate change

\section{Background}

The German National Forest Inventory (NFI) provides important information on tree species composition, forest structure, yield and growth, as well as the composition of ground vegetation and the amount of deadwood (BMEL 2016). It is the basis for the estimation of carbon sequestration in forests and future wood supply at the national scale (Cienciala et al. 2008; Tomppo et al. 2010; Dunger et al. 2012; BMEL 2016). The permanent plots are a representative sample of the forested areas across Germany, hence cover a wide range of climatic and soil conditions. In order to provide a basis for understanding the effects of climate, soil and site conditions on the vitality and productivity of forests in Germany,

Handling Editor: Erwin Dreyer

Contribution of the co-authors Paul Schmidt-Walter created the databases and supplementary material, and drafted the manuscript. All co-authors contributed to the writing and the design of the database. Henning Meesenburg and Tobias Mette additionally supervised the research project.

This article is part of the topical collection on Environmental data for the German NFI

Paul Schmidt-Walter paul.schmidt-walter@nw-fva.de
NFI data were connected with regionalized climate data (Dietrich et al. 2019) and representative soil profiles, which were extracted from various soil information sources (Petzold and Benning 2017). We used the soil and climate data to apply the LWF-BROOK90 hydrological model (Hammel and Kennel 2001) in order to obtain plot-level estimates of water fluxes, soil moisture conditions and drought stress. Various studies on climate sensitivity of tree growth have shown that these factors are indicative of forest productivity in general and growth depressions in particular (Lebourgeois et al. 2005; Friedrichs et al. 2009; Michelot et al. 2012), which motivated us to assemble the NFI water budget, soil moisture and drought stress indicator database (NFIWADS). 


\section{Material and Methods}

\subsection{Locations, plot selection and temporal coverage}

The water balance simulation results are one of the four environmental databases of the German NFI (Mette et al. 2018). The water balance simulations were carried out for the inventory plots of the basic $4 \times 4 \mathrm{~km}$ NFI sampling grid. Each node of the NFI sampling grid is represented by an inventory cluster, which consists of up to four inventory plots. For all NFI inventory plots with available soil and climate data, two sitespecific water balance simulations were carried out for a retrospective period (1961-2013) and for each of three climate change scenarios (2011-2050). For each climate representation, the two simulations describe the hydrological conditions at the NFI plots for mature, closed-canopy pure stands of the most common deciduous tree species, European beech (Fagus sylvatica $\mathrm{L}$.) and the most common coniferous tree species, Norway spruce (Picea abies [L.] H. Karst), in Germany. In total, 24,610 plots from 8800 inventory clusters were used for the simulations, with a mean annual (1961-1990) temperature and annual precipitation sum ranging from 2.1 to $10.9^{\circ} \mathrm{C}$, and 435 to $2923 \mathrm{~mm}$, respectively.

\subsection{Model description}

We used the process-based, one-dimensional soil-vegetationatmosphere-transport model LWF-BROOK90 (Hammel and Kennel 2001) to derive the basic data for the NFIWADS database. The model simulates daily evapotranspiration and soil water fluxes, along with soil water contents and soil water potentials of a soil profile covered with vegetation. It is a modified version of the original BROOK90 hydrological model (Federer 2002; Federer et al. 2003). Both versions have demonstrated their potential in many studies, proving their ability to capture the temporal variation of both water flow components and soil moisture content of forests stands (Armbruster et al. 2004; Schwärzel et al. 2009; Baumgarten et al. 2014; Vilhar 2016). The main differences of LWFBROOK90 compared with the original model version concern the description of soil hydraulic properties and the option to use dynamic, temperature-driven vegetation characteristics in the simulation. Soil hydraulic properties were parameterised using the expressions of van Genuchten (1980) and Mualem (1976). The soil profile is represented by multiple layers, and the vertical water movement through these layers is described according to Darcy's law and the continuity equation (Richards 1931), taking root water uptake and macroporeassisted infiltration into account. The lower boundary of the profile is defined as the unit gradient gravitational water flow from the lowest soil layer. Groundwater inflow and interflow at sloped sites is not accounted for. Evapotranspiration is estimated using the approach of Shuttleworth and Wallace
(1985), modified to differentiate between day-time and night-time evapotranspiration. The method is based on the Penman-Monteith equation (Monteith 1965) and separately estimates the vapour fluxes originating from a 'single big leaf' plant layer (transpiration and interception evaporation) and the ground surface (soil and snow evaporation), using a water vapour conductivity model. An important controlling variable is the leaf area index (LAI), which is used to partition available energy between plant and soil according to Beer's law, to determine rainfall interception storage capacity and catch rates and to scale stomatal conductance to the canopy level. Stomatal conductance is calculated from maximum leaf conductance, which is reduced for unfavourable temperature, vapour pressure deficit and global radiation following the model of Jarvis (1976). The calculated water demand of the canopy (potential transpiration) is covered by a water supply rate (actual transpiration) that depends on plant conductivity as well as the individual water availability and root length density in each soil layer. If water availability in the rooting zone is limited, actual transpiration is reduced below potential transpiration.

\section{Model input}

\subsection{Meteorological data}

LWF-BROOK90 requires daily precipitation, global solar radiation, minimum and maximum air temperature, average vapour pressure and average wind speed. The data were extracted from climate grids with a $250-\mathrm{m}$ resolution, as described in Dietrich et al. (2019). All climate parameters are valid for a reference height of $2 \mathrm{~m}$ above the ground. The data cover a retrospective period (1961-2013) and three climate projections (2011-2050). The climate change scenarios were simulated with the STARS 2.4 model (Orlowsky et al. 2008) and are based on the MPI-ESM ECHAM6 RCP scenarios 2.6, 4.5 and 8.5 (Stevens et al. 2013).

\subsection{Soil profile data}

Soil physical properties (texture, bulk density and coarse fragments) were extracted from the NFI soil profile database (Petzold and Benning 2017), which assigns the one or two predominant soil units to each inventory plot, based on their areal share within a radius of $20 \mathrm{~m}$ around the plot centre. The soil units are uniquely associated with representative soil profiles, which were compiled and harmonised by federal soil experts from the various soil surveys and site evaluation systems of the federal states of Germany.

The soil profiles contain soil physical information for each horizon. If needed, missing soil physical information for single horizons was completed by inter- or extrapolating from 
adjacent horizons. Soil profiles were extended to a minimum soil depth of $2 \mathrm{~m}$, if not constrained by solid bedrock. In total, 8528 different soil profiles could be used, covering 24,610 NFI plots from 8800 inventory clusters. If two soil units were assigned to one inventory plot, the soil profile with the higher areal share was selected for the simulation. Soil hydraulic properties (soil water retention function and hydraulic conductivity function) were derived from the soil physical properties of the respective horizons using pedotransfer functions (PTF), which were selected according to a systematic evaluation of several PTF with respect to measured hydraulic properties (von Wilpert et al. 2016). For mineral soil layers, water retention parameters $\left(\theta_{s}, \theta_{r}, \alpha, n\right.$, as in van Genuchten 1980) were estimated from tabulated values of porosity, water content at field capacity and wilting point (DIN4220 2008), using the software RETC (van Genuchten et al. 1991). The parameter $m$ was calculated as $m=1-1 / n$. The parameters of the conductivity function $\left(K_{s}, \tau\right.$, as in Mualem 1976) were derived using tabulated values from Wessolek et al. (2009). For organic soil horizons, retention and conductivity parameters were taken from Wösten et al. (1999). After establishing soil hydraulic properties, the soil profile depth discretisation was constructed by slicing the horizons into model layers of increasing thickness (from 1 to $2 \mathrm{~cm}$ at the top to $20 \mathrm{~cm}$ at the bottom of the profiles), with the original horizon boundaries being preserved. The fine root density depth distribution was estimated from horizon depth, physical properties and site parameters using a statistical model (von Wilpert et al. 2016). The rooting depth was limited to a maximum soil depth of $160 \mathrm{~cm}$ (Czajkowski et al. 2009). In addition, rooting depth was constrained if root penetration barriers, such as solid bedrock or impermeable soil layers, were present in a soil profile. The lower boundary of all soil profiles was formed by two standard model layers with a coarse grain texture and an overall thickness of $40 \mathrm{~cm}$, in order to determine a uniform lower boundary. As no information on forest floor horizons was present in the soil data, a standard uniform, root-free forest floor horizon of $6 \mathrm{~cm}$ thickness was added to each soil profile, in order to provide uniform soil evaporation conditions (cf. Thiele et al. 2017).

\subsection{Vegetation properties}

In the water balance simulations, two vegetation parameter sets were defined to reflect the different hydrological behaviour of mature, closed-canopy forest stands of European beech and Norway spruce, respectively (Table 1). The parameter sets were adapted from standard parameter sets for temperate deciduous and evergreen conifer forests (Federer et al. 1996). Modifications were made to fit interception evaporation and soil water content dynamics measured at Level II intensive monitoring plots in Germany (ICP Forests 2016). The most crucial differences between the two parameter sets are the characteristic intra-annual variations in LAI of deciduous beech and evergreen spruce, which results in contrasting seasonal courses of canopy conductance and energy partitioning, as well as interception capacity and catch rates. Inter-annual variation of stand characteristics was neglected, i.e. it was assumed that no long-term vegetation development took place. Phenological phases were determined dynamically. The start of the vegetation period (onset of leaf flush) was derived using the degree-day approach described in Menzel (1997), which is parameterised for European beech and Norway spruce. The end of the vegetation period (onset of leaf fall) was estimated using the method of von Wilpert (1990), where the vegetation period is either restricted by a temperature or a day length criterion, whichever is met first.

\section{Model output and data processing}

LWF-BROOK90 calculates daily potential and actual transpiration $\left(T_{p}\right.$ and $\left.T_{a}\right)$, evaporation of intercepted rain $\left(I_{R}\right)$ and snow $\left(I_{S}\right)$, soil and snow evaporation $\left(E_{s l}\right.$ and $\left.E_{s n}\right)$, drainage $(D)$, surface runoff $(R)$ and other water budget variables, along with daily soil water content $\left(\theta_{i}\right)$ and soil water potential $\left(\Psi_{i}\right)$ for each soil layer (see Federer 2002 for a detailed flow chart). In total, simulations for 53 years of the retrospective simulation period (1961-2013) and for 40 years for each of the three climate projections (2011-2050), each for two stand types and 24,610 inventory plots, were conducted, resulting in $8,515,060$ simulation years with a daily data resolution. From the variables obtained, indicators representing daily soil moisture conditions and soil drought stress of (1) the topsoil $(0-30 \mathrm{~cm})$ and $(2)$ the entire root zone were derived from the layer-wise soil water content and soil water potential. For the two depth representations, total soil water storage $S$, plant available water storage $A$, relative soil water storage $R S$ and relative extractable water $(R E W$, Granier et al. 1999) were calculated as

$S=\sum_{i=1}^{n} \theta_{i} *\left(1-c_{i}\right) * d_{i}$,

$A=\sum_{i=1}^{n}\left(\theta_{i}-\theta w p_{i}\right) *\left(1-c_{i}\right) * d_{i}$,

$R S=\frac{S}{F C}, \quad F C=\sum_{i=1}^{n} \theta f c_{i} *\left(1-c_{i}\right) * d_{i}$

$R E W=\frac{A}{A W C}, \quad A W C=\sum_{i=1}^{n}\left(\theta f c_{i}-\theta w p_{i}\right) *\left(1-c_{i}\right) * d_{i}$,

with $\theta_{i}$ being the volumetric water content fraction of the fine earth in the $i$ th soil layer, $c_{i}$ is the volume fraction of coarse fragments (gravel and stones) and $d_{i}$ is the layer thickness in $\mathrm{mm} . A W C$ is plant available soil water storage capacity, $F C$ is field capacity, $\theta f c_{i}$ and $\theta w p_{i}$ represent field capacity and wilting point water contents at pressure heads of -6.3 and $-1585 \mathrm{kPa}$, respectively. Mean daily soil water potential 
(PSI) was calculated from log-transformed $\Psi_{i}$, weighed by fine earth volume $\left(1-v_{i}-c_{i}\right)$ of the respective soil layer:

$P S I=-10^{\sum_{i=1}^{n} \log 10\left(-\Psi_{i}\right) *\left(1-v_{i}-c_{i}\right) * d_{i} / \sum_{i=1}^{n}\left(1-v_{i}-c_{i}\right) * d_{i}}$,

where $\Psi_{i}$ represents the soil water potential of soil layer $i$, and $v_{i}$ is the porosity of that layer.

The transpiration deficit was expressed as difference and ratio between actual $\left(T_{a}\right)$ and potential transpiration $\left(T_{p}\right)$. In LWF-BROOK90, soil water deficits reduce actual transpiration below potential transpiration. The ratio $T_{a} / T_{p}$ (transpiration ratio, TR; Zierl 2001) thus indicates drought stress by values below unity, whereas the difference $T_{p}-T_{a}$ (transpiration difference, $T_{\text {Diff }}$; Schultze et al. 2005) indicates drought stress by values greater than zero.

In order to ease data handling by reducing the overall size of the data, all daily variables were aggregated to (1) monthly values and (2) yearly values integrating the time interval between beginning and end of the dynamic vegetation period. The aggregates were designed to keep most of the information contained by the respective daily variables. To illustrate the aggregation procedure and database output, exemplary results from the retrospective beech data for a single NFI plot (inventory cluster 16,699, plot 2) are shown for the years 2002 and 2003 in Fig. 1. For temporal aggregation, daily water budget variables and $T_{\text {Diff }}$ were summed up to monthly totals (Fig. 1A). For the soil moisture condition variables and the transpiration ratio, overall mean and minimum values were calculated for the respective time intervals, of which monthly mean $S$, $R E W$ and $P S I$ are shown in Fig. 1B and C. More complex monthly and growing season representations of daily drought stress include indicators quantifying the duration and intensity of periods with limited water availability, in which soil water availability falls below critical limits. These periods can be quantified by counting the number of days and the number of consecutive days below or above a critical threshold value or as a deficit sum integrating the intensity values below or above a certain threshold. Accordingly, the number of days $\left(d \_R E W_{C L}\right)$, on which relative extractable soil water $(R E W)$ falls below a critical limit $C L_{R E W}$, and the corresponding intensity $\left(v_{-} R E W_{C L}\right.$, Fig. 1B), were calculated as: $d \_R E W_{C L}=\sum_{j=b e g}^{e n d}\left\{\begin{array}{l}R E W_{j}<C L_{R E W}: 1 \\ R E W_{j} \geq C L_{R E W}: 0\end{array}\right.$

$\nu_{-} R E W_{C L}=\sum_{j=b e g}^{\text {end }}\left\{\begin{array}{c}R E W_{j}<C L_{R E W}: 1-\left(R E W_{j} / C L_{R E W}\right) \\ R E W_{j} \geq C L_{R E W}: 0\end{array}\right.$,

with beg and end marking the beginning and end of the integration interval, respectively, and $R E W_{j}$ (Fig. 1B) being the relative extractable water on day $j$. Both indicators were computed on a monthly basis and per vegetation period, using two levels of $C L_{R E W}(0.2,0.4$; Granier et al. 1999; Bréda et al. 2006), referring to the topsoil and rooting zone, respectively. Similarly, threshold-based drought stress indicators were calculated from the transpiration ratio $\left(T R_{j}\right)$ :

$$
\begin{aligned}
& d_{-} T R_{C L}=\sum_{j=\text { beg }}^{\text {end }}\left\{\begin{array}{l}
T R_{j}<C L_{T R}: 1 \\
T R_{j} \geq C L_{T R}: 0
\end{array}\right. \\
& v_{-} T R_{C L}=\sum_{j=\text { beg }}^{\text {end }}\left\{\begin{array}{l}
T R_{j}<C L_{T R}: 1-\left(T R_{j} / C L_{T R}\right) \\
T R_{j} \geq C L_{T R}: 0
\end{array},\right.
\end{aligned}
$$

with the critical limit $C L_{T R}$ set to two levels, 0.8 and 0.5 (Schulze 2000; Wellpott et al. 2005; Schwärzel et al. 2009). A third set of drought stress indicators was computed from the daily mean soil water potential $P S I_{j}$ (brown line in Fig. 1C), also quantifying the duration days and sum of soil water potential below a critical limit of $C L_{\psi}=-120 \mathrm{kPa}$, below which growth reduction was reported (von Wilpert 1991):

$$
\begin{aligned}
& d_{-P S I_{C L}}=\sum_{i=b e g}^{\text {end }}\left\{\begin{array}{l}
P S I_{j}<C L_{\psi}: 1 \\
P S I_{j} \geq C L_{\psi}: 0
\end{array}\right. \\
& v P_{P S I_{C L}}=\sum_{i=b e g}^{\text {end }}\left\{\begin{array}{c}
P S I_{j}<C L_{\psi}: \psi_{C L}-P S I_{j} \\
P S I_{j} \geq C L_{\psi}: 0
\end{array} .\right.
\end{aligned}
$$

Apart from drought stress, persistent waterlogging can also affect forest health and forest growth. On waterlogged soils, insufficient aeration may reduce fine root growth and forest stress resilience (Thomas and Hartmann 1998; Gaertig et al. 2002) and also increase the risk of windthrow (Panferov et al. 2009; Schmidt et al. 2010). In order to complete the description of the water regime at the NFI plots to incorporate
Table 1 Vegetation parameter sets for European beech and Norway spruce stands, modified from Federer et al. (1996). Minimum and maximum values refer to intra-annual variability (summer/winter)

\begin{tabular}{lll}
\hline & Spruce & Beech \\
\hline Leaf area index $\left(\mathrm{m}^{2} \mathrm{~m}^{-2}\right)(\mathrm{max} / \mathrm{min})$ & $5.5 / 4.4$ & $6 / 0.6$ \\
Maximum canopy conductance $\left(\mathrm{mm} \mathrm{s}^{-1}\right)(\mathrm{max} / \mathrm{min})$ & $19.25 / 15.4$ & $25.2 / 2.52$ \\
Canopy rain interception capacity $(\mathrm{mm})(\mathrm{max} / \mathrm{min})$ & $1.5 / 1.28$ & $0.76 / 0.436$ \\
Rain interception catch rate $(-)(\mathrm{max} / \mathrm{min})$ & $0.8 / 0.668$ & $0.85 / 0.31$ \\
Leaf width $(\mathrm{cm})$ & 0.4 & 5 \\
Albedo $(-)$ & 0.14 & 0.18 \\
Albedo, ground covered with snow $(-)$ & 0.14 & 0.23 \\
\hline
\end{tabular}


waterlogging, the minimum soil depth at which the soil is water-saturated, if ever, was extracted from layer-wise daily water contents. From the saturation depth (zsat), the means, minima and maxima were calculated on both a monthly and vegetation period basis (Fig. 1C). In addition, all days and consecutive days were counted, on which free soil water occurred in soil depths above a reference soil depth $z_{\text {ref }}$ :

$d_{-} S A T_{\text {zref }}=\sum_{i=b e g}^{\text {end }}\left\{\begin{array}{c}z s a t_{j}<z_{\text {ref }}: 1 \\ z s a t_{j} \geq z_{\text {ref }}: 0\end{array}\right.$,

with the reference soil depths chosen at 30 and $60 \mathrm{~cm}$.

In this way, the database provides comprehensive information on the hydrological status of each NFI plot. For example, plot $16,699 / 2$ (Fig. 1) on average receives $800 \mathrm{~mm}$ rain per year (1981-2010), of which $598 \mathrm{~mm}$ is returned to the atmosphere through transpiration $(315 \mathrm{~mm})$, interception $(184 \mathrm{~mm})$ or ground evaporation $(99 \mathrm{~mm})$. The remaining amount $(203 \mathrm{~mm})$ is routed to groundwater or surface waters, predominantly as drainage $(D)$ from the soil profile. Due to a percolation barrier at a soil depth of $50 \mathrm{~cm}$, excess water gathers in the soil profile when transpiration ceases in autumn, sometimes approaching the soil surface. When the complete soil profile is saturated for a longer time, as it was the case in January 2003 (Fig. 1C), surface runoff $(R)$ is generated (Fig. $1 \mathrm{~A})$. The soil properties also form a root barrier, so that the effective rooting depth and plant available water capacity at the site are rather low. This results in rapid soil water depletion due to water uptake during summer, with the relative extractable water $(R E W)$ frequently falling below the critical limit of $C L_{R E W}=0.4$ (Fig. 1A), indicating drought stress. The summer of 2003 was extraordinarily dry, causing a considerable transpiration deficit $\left(T_{D i f f}\right)$ of about $80 \mathrm{~mm}$ in August and September.

\subsection{Reproducibility of results and software used}

All water balance simulations were carried out with the model LWF-BROOK90 (Version 1.2). To facilitate automation and parallelisation, we developed the software package "b90nfiwads" for the free software environment $R$ (R Core Team 2015). The package loads an interface ("brook $90 r$ ", Schmidt-Walter 2018a) between the $R$ environment and the command line tool of the LWF-BROOK90 executable code. For a single site, "brook90r" writes input files from model
Fig. 1 Aggregated water budget and drought stress indicators at the NFI inventory cluster 16,699 , plot 2, simulated using the beech parameter set. (a) Monthly transpiration difference $\left(T_{D i f f}\right)$ and water fluxes of transpiration $\left(T_{a}\right)$, rain and snow interception evaporation $\left(I_{R}, I_{S}\right)$, soil and snow evaporation $\left(E_{s l}, E_{s n}\right)$, drainage $(R)$, surface runoff $(D)$ and precipitation $(P)$. Negative values indicate drainage to groundwater and surface runoff, positive values indicate fluxes to and from the atmosphere. (b) Daily (lines) and monthly (symbols) total ( $S$, $S_{\text {avg }}$ ) and plant available relative $\left(R E W, R E W_{\text {avg }}\right.$ ) root zone water storage, (c) daily (PSI, line) and monthly soil water potential $\left(P S I_{\text {avg }}\right.$, circles) and maximum water table depths ( $z s a t_{\max }$, tildes) (c). Drought stress indicators $T_{\text {Diff }}$ (a), $v_{-} R E W_{C L}$ (b) and $v_{-} P S I_{C L}(\mathbf{c})$ are marked as hatched areas

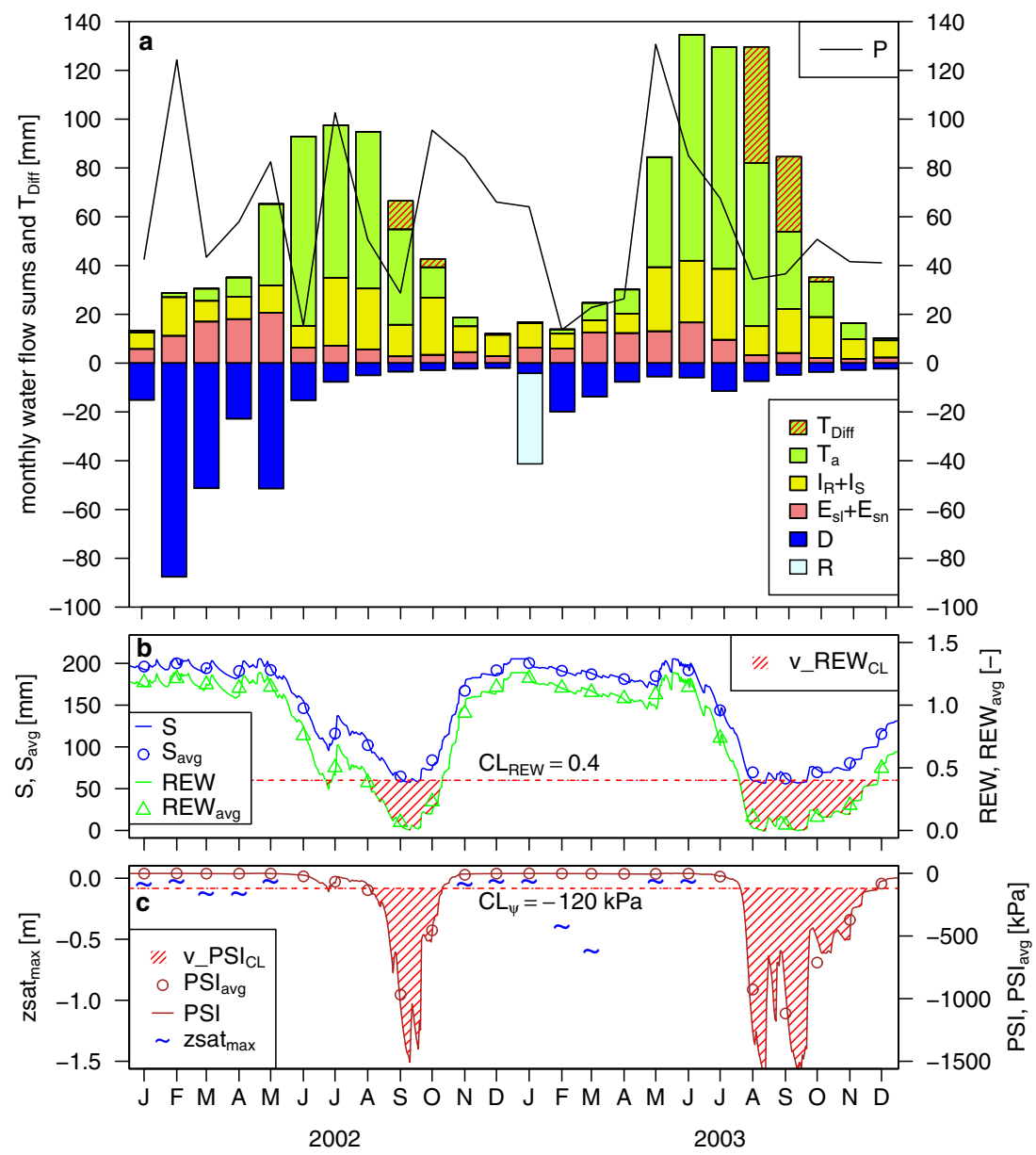


control options, parameters, and climate data, and then executes the command line tool and returns the simulation results. The "b90nfiwads" package extends the functionality of the "brook90r" interface, by providing functions for running LWF-BROOK90 on a sequence of sites in parallel, and further functions for aggregating the model output to the desired monthly and vegetation period representations. The Rpackage is part of the supplementary material of the data and can be accessed in the Zenodo repository (Schmidt-Walter 2018 b) at https://zenodo.org/record/1491520\#. XIJpWChKiUk. With the input data, and the model control options and parameters of the NFI plots set up in the accompanying $\mathrm{R}$ scripts provided, the full reproducibility of the datasets is ensured.

\section{Access to data and metadata description}

The NFIWADS database is available in the Open Agrar repository (Schmidt-Walter et al. 2018) at https://www.openagrar. de/receive/openagrar_mods_00044576. It comprises eight database files (sqlite-format), which contain separate results and description tables for each of the two tree species in each climate representation (the retrospective period and three climate change scenarios). Each database file features seven tables, of which two tables provide the simulation results on a monthly and vegetation period basis (e.g. nfiwads_beech 19612013_monthly, nfiwads_beech_19612013_vegper) and one contains information on the execution time of the individual simulations (e.g. simtime_beech_19612913). The three tables $z_{-} d b, z_{-} t a b, z_{-}$col provide descriptions of the databases, the tables included and the columns featured by

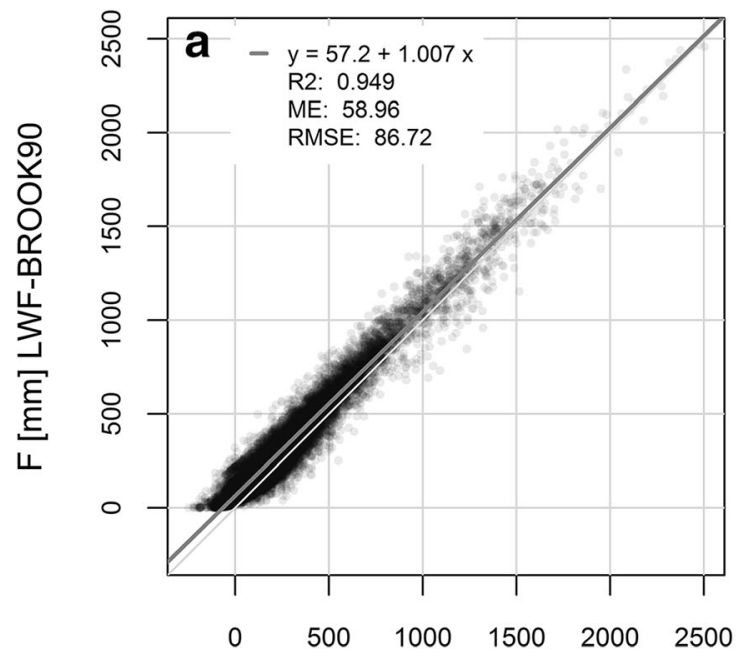

$\mathrm{F}[\mathrm{mm}] \mathrm{TUB}-\mathrm{BGR}$ the tables. Information about the applied model version and input parameter sets, as well as the version names of climate and soil parameters are provided by the table $z$ parameter version. Each database file additionally contains four data views, which select or aggregate basic result sets of the simulation results and provide a starting point for exploring the featured data. The tables and views can be linked by the primary keys TNR and ENR, which identify the NFI inventory cluster and plot, or by an id variable composed of TNR and ENR. More information on the dataset can be found in the metadata file, which can be accessed at https://metadataafs.nancy.inra.fr/geonetwork/srv/fre/catalog.search\#/ metadata/2f09d81c-b663-48a0-8b84-0b247bba6d35. The metadata file contains tables for (1) data provision and discovery, (2) contextual information on the simulation and data processing software and on the origin of the input data and (3) a technical documentation containing a description of each variable name, the corresponding abbreviation used in the text of this manuscript (if applicable), as well as the technical data types, units and the value ranges.

\section{Technical validation}

We checked the consistency of the simulation results by evaluating the soil water mass balance:

$P=I_{R}+I_{S}+T_{a}+E_{s l}+E_{s n}+D+R+\Delta S$,

where $P$ is precipitation and $\Delta S$ is the change in total water storage of the soil profile. Mass balance errors over the complete retrospective simulation period (1961-2013) were not directed to positive or negative values and within an

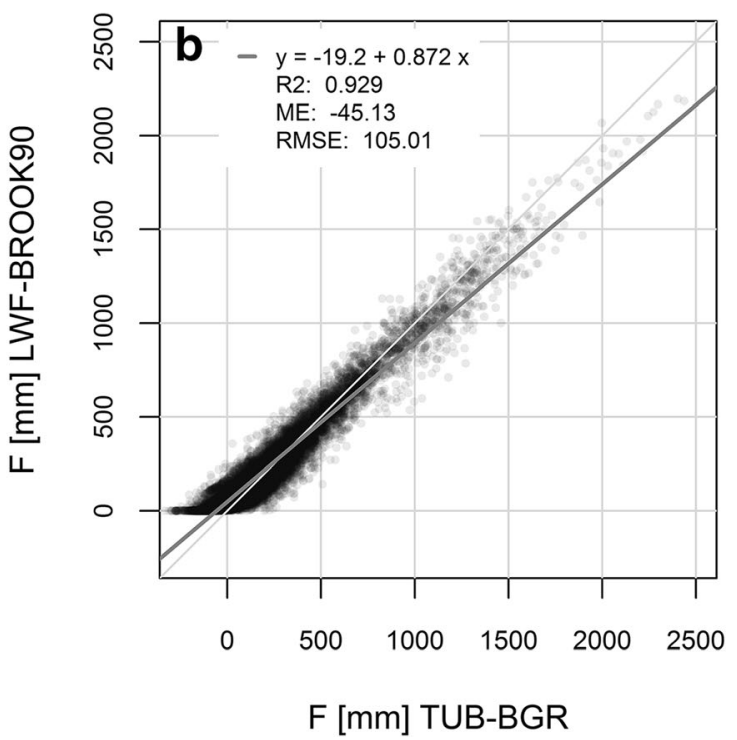

Fig. 2 Comparison between mean annual discharge $(F)$ as the sum of drainage $(D)$ and surface runoff $(R)(1981-2010)$ for beech (a) and spruce (b), computed with the TUB-BGR method and LWF-BROOK90 
acceptable range $( \pm 5 \mathrm{~mm})$. This indicates only minor violations of mass conservation, probably due to integration and precision errors. We also checked the mean total discharge $F=D+R$ against values computed using the TUB-BGR method (Wessolek et al. 2008; Ahrends et al. 2018). TUBBGR is hydro-pedotransfer function to calculate mean annual percolation rates, which is parameterised for different land use types, including conifer evergreen and deciduous forests. Using the beech forest parameter set, the mean total discharge (1981-2010) calculated with LWF-BROOK90 agreed very well with the values computed for deciduous forests using TUB-BGR (Fig. 2A). However, in contrast to LWFBROOK90, TUB-BGR accounts for capillary rise and also allows negative water balances, causing a systematic deviation of the regression line from the bisector and a mean error (ME) of $59 \mathrm{~mm}$. For spruce, there is a slightly stronger deviation of the total mean discharge calculated with the conifer forest parameter set in TUB-BGR (Fig. 2B). The slope of the regression line is significantly below unity, indicating a lower discharge derived using LWF-BROOK90. The deviance might arise from the conifer forest parameterisation in TUBBGR, which does not differentiate between pine and spruce forests. Pine forests achieve lower interception rates compared to spruce (Meesenburg et al. 2014). Thus, the total discharge from the conifer forest parameterisation in TUB-BGR might be higher than that from spruce stands, which are represented in the results computed with LWF-BROOK90.

\section{Reuse potential and limits}

The database contains plot level water fluxes, soil moisture conditions and drought stress indicators for mature, closed-canopy beech and spruce stands. Regardless of the forest types present at the forest inventory plots and of their individual development over time due to growth, thinning and other disturbances, the physical characteristics (e.g. LAI, stand height, and root distribution) of these stands were kept constant in space and time. Therefore, the simulation results for beech and spruce do not reflect the 'real' hydrological status, which would adjust to the actual forest vegetation, but rather may be regarded as land-use scenarios for the NFI plots. This approach is in accordance with a simplified 'indicator stand' concept (Thiele et al. 2017), aimed at extracting the combined climate and soil effect on water availability, related forest productivity conditions and potential risk factors. The effects of climate and soil are, in fact, the only sources of variation in our water balance simulation results. Thus, the provided water fluxes, soil moisture conditions and drought stress indicators for the two forest types can primarily serve as predictors for analysing climate-sensitive site-productivity relationships and risk potentials, when connected to the yield and mortality data of the NFI.
Aside from fields of application where rather long-term mean values of water availability are required, the various monthly and seasonal variables can also serve as predictors in applications that focus on the inter-annual and intra-annual variability of forest growth and forest vitality, as preserved in tree-ring chronologies and surveyed by annual crown condition and defoliation inventories. The latter field of application, in particular, appears promising, as drought seems to have superseded acid deposition and soil acidification as main driving factors of defoliation in Germany during the past 15 years (Augustin et al. 2009).

However, for investigations of inter-annual and intraannual variation of forest productivity and vitality, it is certainly advantageous to use indicators for water availability that were computed using actual stand characteristics and their development over time. Nevertheless, as long as the actual stand characteristics do not differ substantially from our standardised, closed-canopy forest stands (e.g. young afforestation, sparse and open forests), the water availability variables provided can be expected to adequately describe the prevailing hydrologic conditions and dynamics of the individual plots. We are confident that the water availability variables provided can explain significant amounts of seasonal and inter-annual variance in the growth of closed-canopy coniferous and deciduous forest stands.

Acknowledgments We thank Thilo Wolf (FVA-BW) for the fast and uncomplicated provision of huge amounts of daily resolution climate data and the Federal Office for Agriculture and Food for the project sponsorship.

Funding information The database was created within the project "Forest productivity, carbon sequestration, climate change" which was funded by the Forest Climate Fund supported by the Federal Ministry of Food and Agriculture and the Federal Ministry for the Environment, Nature Conservation, Building and Nuclear Safety by decision of the German Bundestag (project no. 28WC4003).

\section{Compliance with ethical standards}

Conflict of interest The authors declare that they have no conflict(s) of interest.

\section{References}

Ahrends B, Sutmöller J, Schmidt-Walter P, Meesenburg H (2018): Beitrag von Waldflächen zur Sickerwasserbildung in Niedersachsen. In: Schütze N, Müller U, Schwarze R, Wöhling T, Grundmann J (eds) "M3 - Messen, Modellieren, Managen in Hydrologie und Wasserresourcenbewirtschaftung", Beiträge zum Tag der Hydrologie am 22./23. März 2018 an der Technischen Universität Dresden. Forum für Hydrologie und Wasserbewirtschaftung 39.18:169-180. https://doi.org/10.14617/ for.hydrol.wasbew.39.18

Armbruster M, Seegert J, Feger K-H (2004) Effects of changes in tree species composition on water flow dynamics - model applications 
and their limitations. Plant Soil 264:13-24. https://doi.org/10.1023/ B:PLSO.0000047716.45245.23

Augustin NH, Musio M, von Wilpert K, Kublin E, Wood SN, Schumacher M (2009) Modeling spatiotemporal forest health monitoring data. J Am Stat Assoc 104:899-911. https://doi.org/10.1198/ jasa.2009.ap07058

Baumgarten M, Weis W, Kühn A, May K, Matyssek R (2014) Forest transpiration - targeted through xylem sap flux assessment versus hydrological modeling. Eur J For Res 133:677-690. https://doi.org/ 10.1007/s10342-014-0796-4

BMEL (2016) Der Wald in Deutschland: Ausgewählte Ergebnisse der dritten Bundeswaldinventur. Bundeministerium für Ernährung und Landwirtschaft, Berlin

Bréda N, Huc R, Granier A, Dreyer E (2006) Temperate forest trees and stands under severe drought: a review of ecophysiological responses, adaptation processes and long-term consequences. Ann For Sci 63:625-644. https://doi.org/10.1051/forest:2006042

Cienciala E, Tomppo E, Snorrason A et al (2008) Preparing emission reporting from forests / use of national forest inventories in European countries. Silva Fenn 42:73-88

Czajkowski T, Ahrends B, Bolte A (2009) Critical limits of soil water availability (CL-SWA) for forest trees - an approach based on plant water status. Landbauforsch Völkenrode 59:87-93

Dietrich H, Wolf T, Kawohl T, Wehberg J, Kändler G, Mette T, Röder A, Böhner J (2019) Temporal and spatial high-resolution climate data from 1961-2100 for the Germany National Forest Inventory (NFI). Ann For Sci 76:6. https://doi.org/10.1007/s13595-018-0788-5

DIN4220 (2008) Bodenkundliche Standortbeurteilung - Kennzeichnung, Klassifizierung und Ableitung von Bodenkennwerten. Beuth, Berlin

Dunger K, Petersson SH-O, Barreiro S, Cienciala E, Colin A, Hylen G, Kusar G, Oehmichen K, Tomppo E, Tuomainen T, Ståhl G (2012) Harmonizing greenhouse gas reporting from European forests: case examples and implications for European union level reporting. For Sci 58:248-256. https://doi.org/10.5849/forsci.10-064

Federer CA (2002) BROOK 90: A simulation model for evaporation, soil water, and streamflow. http://www.ecoshift.net/brook/brook90.htm. Accessed 2 Dec 2018

Federer CA, Vörösmarty C, Fekete B (1996) Intercomparison of methods for calculating potential evaporation in regional and global water balance models. Water Resour Res 32:2315-2322. https://doi.org/ 10.1029/96WR00801

Federer CA, Vörösmarty C, Fekete B (2003) Sensitivity of annual evaporation to soil and root properties in two models of contrasting complexity. J Hydrometeorol 4:1276-1290. https://doi.org/10. 1175/1525-7541(2003)004<1276:SOAETS $>2.0 . C O ; 2$

Friedrichs DA, Trouet V, Büntgen U, Frank DC, Esper J, Neuwirth B, Löffler J (2009) Species-specific climate sensitivity of tree growth in Central-West Germany. Trees 23:729-739. https://doi.org/10.1007/ s00468-009-0315-2

Gaertig T, Schack-Kirchner H, Hildebrand EE, Wilpert KV (2002) The impact of soil aeration on oak decline in southwestern Germany. For Ecol Manag 159:15-25. https://doi.org/10.1016/S0378-1127(01) 00706-X

Granier A, Bréda N, Biron P, Villette S (1999) A lumped water balance model to evaluate duration and intensity of drought constraints in forest stands. Ecol Model 116:269-283. https://doi.org/10.1016/ S0304-3800(98)00205-1

Hammel K, Kennel M (2001) Charakterisierung und Analyse der Wasserverfügbarkeit und des Wasserhaushalts von Waldstandorten in Bayern mit dem Simulationsmodell BROOK90. Forstl. Forschungsberichte München 185

ICP Forests (2016) Manual on methods and criteria for harmonized sampling, assessment, monitoring and analysis of the effects of air pollution on forests. Thünen Institut of Forest Ecosystems, Eberswalde, Germany
Jarvis PG (1976) The interpretation of the variations in leaf water potential and stomatal conductance found in canopies in the field. Philos Trans R Soc Lond Ser B 273:593-610. https://doi.org/10.1098/rstb. 1976.0035

Lebourgeois F, Bréda N, Ulrich E, Granier A (2005) Climate-tree-growth relationships of European beech (Fagus sylvatica L.) in the French permanent plot network (RENECOFOR). Trees 19:385-401. https://doi.org/10.1007/s00468-004-0397-9

Meesenburg H, Ahrends B, Kallweit R et al (2014) Interzeption von Wäldern: eine $(\mathrm{zu})$ wenig beachtete Größe des Wasserkreislaufs. Forum für Hydrol Wasserbewirtsch 34:199-206

Menzel A (1997) Phänologie von Waldbäumen unter sich ändernden Klimabedingungen - Auswertung der Beobachtungen in den Internationalen Phänologischen Gärten und Möglichkeiten der Modellierung von Phänodaten. Forstl Forschungsberichte München 164

Mette T, Amberger H, Ahrends B et al (2018) BWI 2012 Umweltdatenbank. Göttingen, Open Agrar Repositorium https:// www.openagrar.de/receive/openagrar_mods_00041957. Accessed 10 Oct 2018

Michelot A, Bréda N, Damesin C, Dufrêne E (2012) Differing growth responses to climatic variations and soil water deficits of Fagus sylvatica, Quercus petraea and Pinus sylvestris in a temperate forest. For Ecol Manag 265:161-171. https://doi.org/10.1016/j.foreco. 2011.10.024

Monteith JL (1965) Evaporation and environment. Symp Soc Exp Biol 19:205-224

Mualem Y (1976) A new model for predicting the hydraulic conductivity of unsaturated porous media. Water Resour Res 12:513-522

Orlowsky B, Gerstengabe F-W, Werner PC (2008) A resampling scheme for regional climate simulations and its performance compared to a dynamical RCM. Theor Appl Climatol 93:209-223. https://doi.org/ 10.1007/s00704-007-0352-y

Panferov O, Doering C, Rauch E, Sogachev A, Ahrends B (2009) Feedbacks of windthrow for Norway spruce and Scots pine stands under changing climate. Environ Res Lett 4:045019. https://doi.org/ $10.1088 / 1748-9326 / 4 / 4 / 045019$

Petzold R, Benning R (2017) Standortskartierung - Wissen von gestern? AFZ der Wald 15:25-28

R Core Team (2015) R: a language and environment for statistical computing. R Foundation for Statistical Computing, Vienna

Richards LA (1931) Capillary conduction of liquids through porous mediums. Physics 1:318-333. https://doi.org/10.1063/1.1745010

Schmidt M, Hanewinkel M, Kändler G, Kublin E, Kohnle U (2010) An inventory-based approach for modeling single-tree storm damage experiences with the winter storm of 1999 in southwestern Germany. Can J For Res 40:1636-1652. https://doi.org/10.1139/ X10-099

Schmidt-Walter (2018a) brook90r - Run the LWF-BROOK90 hydrological model from within $R$. V1.0.1. Zenodo. [Dataset]. https://doi.org/ 10.5281/zenodo. 1433676

Schmidt-Walter (2018b) Supplementary material for dataset "NFIWADS: The water budget, soil moisture, and drought stress indicator database for the German National Forest Inventory (NFI). V0.1.1. Zenodo. [Dataset]. https://doi.org/10.5281/zenodo.1478798

Schmidt-Walter P, Ahrends B, Mette T, Puhlmann H, Meesenburg H (2018) NFI 2012 water budgets and drought stress indicators database. V 08 march 2018. Open Agrar Repositorium. [Dataset]. https://doi.org/10.3220/DATA/20181108-095429

Schultze B, Kölling C, Dittmar C (2005) Konzept für ein neues quantitatives Verfahren zur Kennzeichnung des Wasserhaushalts von Waldböden in Bayern. Forstarchiv 76:155-163

Schulze E-D (ed) (2000) Carbon and nitrogen cycling in European forest ecosystems. Springer, Berlin Heidelber, pp 506

Schwärzel K, Feger K-H, Häntzschel J, Menzer A, Spank U, Clausnitzer F, Köstner B, Bernhofer C (2009) A novel approach in model-based 
mapping of soil water conditions at forest sites. For Ecol Manag 258:2163-2174. https://doi.org/10.1016/j.foreco.2009.03.033

Shuttleworth WJ, Wallace JS (1985) Evaporation from sparse crops - an energy combination theory. Q J R Meteorol Soc 111:839-855. https://doi.org/10.1002/qj.49711146910

Stevens B, Giorgetta M, Esch M, Mauritsen T, Crueger T, Rast S, Salzmann M, Schmidt H, Bader J, Block K, Brokopf R, Fast I, Kinne S, Kornblueh L, Lohmann U, Pincus R, Reichler T, Roeckner E (2013) Atmospheric component of the MPI-M earth system model: ECHAM6. J Adv Model Earth Syst 5:146-172. https://doi.org/10.1002/jame.20015

Thiele JC, Nuske RS, Ahrends B, Panferov O, Albert M, Staupendahl K, Junghans U, Jansen M, Saborowski J (2017) Climate change impact assessment - a simulation experiment with Norway spruce for a forest district in Central Europe. Ecol Model 346:30-47. https:// doi.org/10.1016/j.ecolmodel.2016.11.013

Thomas FM, Hartmann G (1998) Tree rooting patterns and soil water relations of healthy and damaged stands of mature oak (Quercus robur L. and Quercus petraea [Matt.] Liebl.). Plant Soil 203:145158. https://doi.org/10.1023/A:1004305410905

Tomppo E, Gschwantner T, Lawrence M, McRoberts RE (eds) (2010) National Forest Inventories: pathways for common reporting. Springer, Berlin

van Genuchten T (1980) A closed-form equation for predicting the hydraulic conductivity of unsaturated soils. Soil Sci Soc Am J 44:892898. https://doi.org/10.2136/sssaj1980.03615995004400050002x

van Genuchten, Leij FJ, Yates SR (1991) The RETC code for quantifying the hydraulic functions of unsaturated soils. US Salinity Laboratory, Riverside

Vilhar U (2016) Comparison of drought stress indices in beech forests: a modelling study. IForest - Biogeosciences For 9:635-642. https:// doi.org/10.3832/ifor1630-008

von Wilpert K (1991) Intraannual variation of radial tracheid diameters as monitor of site specific water stress. Dendrochronologia 9:95-113 von Wilpert, K (1990) Die Jahrringstruktur von Fichten in Abhängigkeit vom Bodenwasserhaushalt auf Pseudogley und Parabraunerde: Ein Methodenkonzept zur Erfassung standortsspezifischer Wasserstressdispostion. Freiburger Bodenkundl. Abh. 24.

von Wilpert K, Hartmann P, Puhlmann H, et al (2016) Bodenwasserhaushalt und Trockenstress. In: Dynamik und räumliche Muster forstlicher Standorte in Deutschland. Ergebnisse der Bodenzustandserhebung im Wald 2006 bis 2008. Johann Heinrich von Thünen-Institut, Braunschweig, pp 343-386. https:// doi.org/10.3220/REP1473930232000

Wellpott A, Imbery F, Schindler D, Mayer H (2005) Simulation of drought for a scots pine forest (Pinus sylvestris L.) in the southern upper Rhine plain. Meteorol Z 14:143-150. https://doi.org/10.1127/ 0941-2948/2005/0015

Wessolek G, Duijnesveld WHM, Trinks S (2008) Hydro-pedotransfer functions (HPTFs) for predicting annual percolation rate on a regional scale. J Hydrol 356:17-27. https://doi.org/10.1016/j.jhydrol. 2008.03.007

Wessolek G, Kaupenjohann M, Renger M (eds) (2009) Bodenphysikalische Kennwerte und Berechnungsverfahren für die Praxis. Bodenökologie und Bodengenese 40, pp 80.

Wösten JHM, Lilly A, Nemes A, Le Bas C (1999) Development and use of a database of hydraulic properties of European soils. Geoderma 90:169-185. https://doi.org/10.1016/S0016-7061(98)00132-3

Zierl B (2001) A water balance model to simulate drought in forested ecosystems and its application to the entire forested area in Switzerland. J Hydrol 242:115-136. https://doi.org/10.1016/ S0022-1694(00)00387-5

Publisher's note Springer Nature remains neutral with regard to jurisdictional claims in published maps and institutional affiliations.

\section{Affiliations}

\section{Paul Schmidt-Walter ${ }^{1}$ (D) $\cdot$ Bernd Ahrends $^{1} \cdot$ Tobias Mette $^{2} \cdot$ Heike Puhlmann $^{3} \cdot$ Henning Meesenburg $^{1}$}

Bernd Ahrends

bernd.ahrends@nw.fva.de

Tobias Mette

tobias.mette@1wf.bayern.de

1 Northwest German Forest Research Institute (NW-FVA), Grätzelstr. 2, 37079 Göttingen, Germany

2 Bavarian State Institute of Forestry (LWF), Hans-Carl-vonCarlowitz-Platz 1, 85354 Freising, Germany
Heike Puhlmann

heike.puhlmann@forst.bwl.de

Henning Meesenburg

henning.meesenburg@nw-fva.de

3 Forest Research Institute Baden-Württemberg (FVA-BW), Wonnhaldestr. 4, 79100 Freiburg im Breisgau, Germany 